\title{
VYBRANÉ OTÁZKY PÔSOBENIA PODNIKOV S MAJETKOVOU ÚLASŞOU MIEST
}

\section{SELECTED ISSUES OF ENTERPRISES WITH THE MUNICIPAL PROPERTY SHARE}

\section{ING. Monika BUMBALOVÁ, PhD. ING. Eva BALÁG̣OVÁ, PHD.}

\author{
Katedra verejnej správy $\mid$ Department of Public Administration \\ Fakulta európskych ğúdií a regionálneho rozvoja Fac. of European Studies and Regional Development \\ Slovenská poŎohospodárska univerzita v Nitre Slovak Agricultural University in Nitra \\ $\bowtie$ Tr. A Hlinku 2, 94976 Nitra, Slovak Republic \\ E-mail: monika.bumbalova@uniag.sk, eva.balazova@uniag.sk
}

\begin{abstract}
Anotácia
Miestne samosprávy v podmienkach Slovenska môǵ samostatne hospodáriડ̌ so svojim majetkom. Jednou z foriem, akou samosprávy majetok vyuğvajú je zakladanie podnikov s majetkovou úlasక̌ou. Napriek tomu, ǵe toto právo je zakotvené v platnej legislatíve, v podmienkach Slovenska neexistuje priama právna úprava hospodárenia podnikov s majetkovou úl asડ̌su miest, ! o v praxi vedie $k$ vzniku mnoǵstva problematických oblastí. Cie@̆m príspevku bolo analyzovaŠ vybrané determinanty hospodárenia podnikov s majetkovou úl as ̌̌su miest a podpornou argumentáciou zadefinovaŠ postoje k vybraným otázkam hospodárenia týchto podnikov. KĞil ovou metódou bola Delfská metóda postavená na dosahovaní názorového konsenzu expertov z teoretického prostredia a praxe. Analýzou bolo zistené, ǵe podniky s majetkovou ú! as ̌̌su miest majú zväl ğa formu s.r.o. Ú! elom zakladania podnikov bola najmä správa mestského majetku a komer|̣n né aktivity nesúvisiace s výkonom kompetencií, ḷ je do budúcnosti ğaduce zmeniŠ Mestá majú tendenciu byŠ 100\%-ným vlastníkom najmä pri s.r.o. a tento trend by mal zostaŠ zachovaný. V prípade výsledku hospodárenia, aǵ tretina podnikov dosahovala stratu, pril om medzi expertami panuje názor, ǵe tieto podniky by mali byŠv budúcnosti zlikvidované alebo transformované. Podiely na zisku do mestských rozpol tov odvádzajú najmä podniky zamerané na výkon kompetencií a nakladanie so ziskom (jeho odvádzanie do rozpoḷ tu mesta alebo spätné investovanie do podniku) by sa malo odvádzaS od okolností, rozhodnutím poslancov MZ. Zo sledovaných podnikov aǵ $64 \%$ je na rozpol ty miest naviazané dodávateăkoodberateăkými vž̌shmi. Ceny za sluǵby poskytované podnikmi mestu by mali byŠ odvodené od reálnych nákladov a výhodné pre obe strany. Implementácia spomenutých zásad by mala vies ̌̌ k efektívnejğiemu hospodáreniu podnikov s majetkovou ú! as ̌̌su miest.
\end{abstract}

KÖ́ḷové slová

podniky s majetkovou úl asక̌ou miest, majetok miest, manağnent samospráv

\section{Annotation}

Local self-governments in Slovakia have the right to manage their property, while setting up an enterprise with the municipal property share is one of the eligible forms. Despite the fact that law stipulates this right, there is no direct legislation covering the enterprises, what in practice leads to many issues. The objective of this paper was to analyze selected determinants of the enterprises and to define approaches towards selected issues of their management. Delphi method, based on reaching consensus of experts from the theory and practice, was the key method used in the study. The analysis proved that the enterprises have usually a form of ltd. and they are mainly oriented on the municipal property management and commercial activities, not connected to the self-government competencies. Preferably this will change in the future. Municipalities usually own $100 \%$ of ltd. enterprises and this trend should be preserved. Almost one third of the enterprises reached a loss, what lead to the 
conclusion that these enterprises need to be either liquidated or transformed. Especially those enterprises oriented on self-government competencies pay a share on their profit to the municipal budgets, while the members of municipal council should adopt the decision about profit. $64 \%$ of enterprises are linked to the municipal budgets by the supplier relations, while prices for the provided services should be based on the real costs and, additionally, beneficial for both parts. Implementation of the approaches should lead to the more effective management of these enterprises.

Key words

enterprises with the municipal property share, municipal property, management of self-government

\section{JEL classification: $H 70$}

\section{Úvod}

Vo viacerých krajinách, najmä západnej a strednej Európy, je miestna samospráva nezávislá a priame zásahy ǵátu do jej kompetencií sú zakázané (Alekseev, 2013). Navyg்e, v prostredí moderných liberálnych demokracií, sa ukazuje neustále narastajúca tendencia smerujúca k aplikácii systému subsidiarity (Paulíl ková, 2010). Na druhej strane stojí teória, ǵe zabezpel enie finan! ných potrieb miestnej samosprávy by malo byŠ nastavené proporcionálne $\mathrm{k}$ výkonu jej kompetencií a úloh (Oplotnik- Brezovnik- Vojinovic, 2012, Klimovský, 2008 a iní).

ÚroveŔ miestnej samosprávy na Slovensku preg̉a procesom decentralizácie a to jednak decentralizácie kompetencií a jednak fig̉kálnou decentralizáciou (Hamalová ï Belajová, 2011). Ekonomická autonómnosŠ slovenských miestnych samospráv je medzi iným identifikovaná ich právom vlastniŠ majetok a hospodáriŠ s ním (zákon !. 369/1990 Zb.). Jedným zo zákonom povolených foriem nakladania s majetkom miestnych samospráv je práve jeho vklad do obchodných spolol ností, ktoré si mestá a obce môǵ zakladaŠ a prostredníctvom nich vykonávaŠ podnikateQ̆kú !̣innosŠ Teória nakladania s obecným majetkom hovorí, ǵe na podnikateQ̆ké úl ely samosprávy spravidla vyuğ́vajú dlhodobý hmotný majetok, ktorý majú k dispozícii po zabezpel ení originálnych a prenesených kompetencií a verejno-prospeg̉ných sluğieb alebo majetok zámerne vyḷ lenený na podnikateQ̆ké úl ely (G̣árska et al. 2007, s. 26).

Príjmy samosprávnych rozpol tov generované prostredníctvom vyuğivania samosprávneho majetku na podnikateQ̆ké úl ely prispievajú k zvyğovaniu finan! nej nezávislosti samospráv (Paulíl ková, 2010) a tieǵ sú dôkazom vysokej úrovne manaǵmentu, keṆǵe predstavujú spôsob generovania vlastných financií bez zvyǵovania daní a poplatkov pre obḷanov (Transparency International, 2007). $\mathrm{Na}$ druhej strane, negatívnu stránku predstavuje fakt, ǵe slovenský právny systém nevytvára dostatol nú východiskovú bázu pre fungovanie takýchto podnikov (Bumbalová, 2013), ! o následne vedie $\mathrm{k}$ tomu, ǵe v praxi existuje mnoǵstvo aspektov a otázok, ktoré nie sú zastreǵené legislatívne ani v teoretických, ! i praktických prístupoch.

Predkladaný príspevok si kladie za úlohu reagovaŠ práve na tieto aspekty a to prostredníctvom identifikácie stavu voblasti hospodárenia podnikov s majetkovou úl asŠu miest, formulácie výskumných otázok a následným dosiahnutím názorového konsenzu viacerých odborníkov z teórie a praxe danej oblasti na konkrétnu otázku.

\section{CieOa metódy}

Príspevok sa zaoberá hodnotením vybraných identifikal ných, majetkových, ekonomických a finan! ných determinantov vyuǵivania majetku miest na podnikateQ̆ké úl ely prostredníctvom podnikov s majetkovou úl as Šou miest. CieŎm príspevku bolo zadefinovaš postoje a ġandardy smerom $\mathrm{k}$ vybraným zásadným otázkam zakladania, fungovania a hospodárenia podnikov $\mathrm{s}$ majetkovou úl asŠou miest. 
Údaje pouğité v príspevku boli zozbierané prostredníctvom dotazníkového prieskumu. Základný súbor predstavovali vġetky samosprávy so ġatútom mesta a návratnoš̌ dotazníka bola 31,2\%. Pre úl ely hodnotenia a analýzy boli skúmané determinanty vyugóvania majetku miest na podnikateQ̆ké úl ely klasifikované podQ̆ ich povahy na dve základné skupiny a to na identifikal né determinanty a na determinanty, ktoré vychádzajú z vlastníckych, ekonomických a obchodných vzŠahov medzi mestami a podnikmi s majetkovou úl as ̌̌ou (tabuăa 1).

Tab. 1: Klasifikácia determinantov

\begin{tabular}{|l|l|}
\hline Oblas $\subseteq$ & Determinanty \\
\hline $\begin{array}{l}\text { Identifikaḷ né } \\
\text { determinanty }\end{array}$ & $\begin{array}{l}\text { celkový pol et podnikov s majetkovou úl asŚou mesta zaloǵených mestom, rok } \\
\text { zaloǵenia podniku, právna forma podniku }\end{array}$ \\
\hline $\begin{array}{l}\text { Determinanty } \\
\text { vlastníckych } \\
\text { ekonomických } \\
\text { a obchodných vzŠahov }\end{array}$ & $\begin{array}{l}\text { výǵka základného imania vloǵeného do podniku mestom, podiel mesta na základnom } \\
\text { imaní, výsledky hospodárenia podniku za roky 2009-2011, príjmy z podniku plynúce } \\
\text { do mestského rozpoḷ tu za roky 2009-2011 a hodnota tovarov a sluǵieb, ktoré podnik } \\
\text { vyfakturoval mestu za obdobie rokov 2009-2011 }\end{array}$ \\
\hline
\end{tabular}

Zdroj: vlastné spracovanie

V rámci hodnotenia vybraných determinantov boli sformulované výskumné otázky, ktoré na základe ich povahy nebolo moǵné zodpovedaŠ zo získaných údajov. Tieto výskumné otázky boli následne hodnotené prostredníctvom Delfskej metódy zaloǵenej na zisŠovaní názorov expertov a dosahovaní názorového konsenzu. Výskumu sa zúl astnilo 7 expertov prị om 3 predstavujú zástupcov $\mathrm{z}$ akademického prostredia a 4 z praxe. Názorový konsenzus v odpovediach expertov bolo moǵné dosiahnuŠ v rámci prvého kola rozposielania výskumných otázok, keṆǵe nijaký z názorov svojou povahou neodporoval ostatným, respektíve ich nepopieral.

\section{Výsledky}

Posudzované determinanty, ktoré majú ekonomický a obchodný charakter boli sledované za referen! né obdobie od roku 2009 do 2011, pri identifikal ných a vlastníckych determinantoch je ! asový rámec irelevantný. Analýza jednotlivých determinantov vyústila do formulácie 5 výskumných otázok, následne zodpovedaných prostredníctvom Delfskej metódy.

\subsection{Hodnotenie vybraných identifikaḷ ných determinantov vyuǵvania majetku miest na podnikateĞké úl ely}

Prvým aspektom na vyhodnocovanie bol rok zaloǵenia podnikov. Obdobie ! astejg̉eho zakladania podnikov bolo v polovici deväŠdesiatych rokov a tieǵ okolo roku 2006. Spolol enské zmeny, ktoré mohli tento vývoj ovplyvniŠ boli prechod z centrálne riadeného na trhové hospodárstvo a tieǵfakt, ǵe v roku 2004 Slovensko vstúpilo do Európskej únie. Tendencie z roku 2006 zas môǵu súvisieŠ s vrcholiacou fig̉kálnou decentralizáciou, kedy sa ukon! il proces prenosu kompetencií a to aj tých, ktoré súvisia s vyuğ́vaním majetku a samosprávy mohli svoj majetok plnohodnotne vyuǵivaŠ Tendencia zakladania podnikov s majetkovou úl asŠou miest je v posledných rokoch relatívne nízka, ! o môǵe napovedaŠfinan! né problémy, ktorým samosprávy v ostatných rokoch ! elia.

Právna forma podnikov s majetkovou úl asŠou miest patrí k významným determinantom, od ktorých sa odvíja podnikanie miest. Pri porovnaní údajov ohădne právnej formy so zameraním podnikov bolo zistené, ǵe aǵ 64\% akciových spolol ností má zameranie iné, ako sú základné kompetencie samospráv, iğo napríklad o g̣portové kluby, hotely, prípadne lokálne televízie. To znalí, ǵe za úl elom poskytovania verejných sluǵieb resp. za úl elom výkonu samosprávnych kompetencií, majú mestá tendenciu zakladaŠ skôr spolo!̣ nosti s rul ením obmedzeným. Dôvodom môǵe byŠ napríklad otázka rul enia, niǵğa administratívna nárol nosડ zakladania takejto spolol nosti a v neposlednom rade tieǵ niğgie základné imanie potrebné na zaloǵenie spolol nosti.

Zameranie podnikov s majetkovou úl asŠou miest, resp. ich orientácia na poskytovanie verejných sluǵieb pre obyvateQ̆tvo predstavuje N̦alğ z podstatných aspektov ich fungovania. Po zjednoduǵení 
definície indikátora a jeho rozdelení na dve skupiny bolo zistené, ǵe pribliǵne polovica podnikov sa zaoberá aktivitami priamo súvisiacimi so samosprávnymi kompetenciami a druhá polovica podnikov má hlavný predmet ḷinnosti orientovaný inak. Priame poskytovanie verejných sluǵeb pre obyvateQ̆tvo, ktoré boli v dotazníku oznal ené ako komunálne sluğby vğak uviedlo len 9\% podnikov, N̦alğ́ch 13\% v kombinácii $\mathrm{s}$ iným zameraním. Z tohto vyplýva, ǵe mestá si svoje podniky s majetkovou úl asŠou nezakladajú primárne za úl elom poskytovania sluǵieb pre obyvateQ̆tvo, ale hădajú spôsoby manaǵovania správy majetku (33\% podnikov), prípadne sa snaǵa o generovanie vlastných finan! ných prostriedkov prostredníctvom ziskov podnikov, pôsobiacich na voĞom trhu, mimo sféry verejných sluğieb.

Otázka zamerania podnikov s majetkovou úl asŠou miest na výkon samosprávnych kompetencií sa javí byŠ kđ̣̆ | ovou, medzi iným, aj pre potreby zadefinovania takýchto podnikov. Preto predstavuje prvú z výskumných otázok, ktoré boli predloǵené expertom v rámci Delfskej metódy.

Dominantný názor, presadzovaný medzi expertmi bol jednoznal ne pozitívny, a teda, ǵe mestá by sa mali zameriavaŠ na zakladanie podnikov orientovaných na výkon samosprávnych kompetencií. Podporným argumentom pre takéto stanovisko bola napríklad aj právna úprava, konkrétne zákon o obecnom majetku, ktorý uvádza, ǵe obec je povinná vyuğvaŠ majetok na samosprávne úl ely, následne na verejné úl ely a aǵnásledne na podnikateQ̆kú ! innosŠ

\subsection{Hodnotenie majetkových, ekonomických a finan!̣ých determinantov vyuǵviania majetku miest na podnikateĞké úl ely}

Prvým sledovaným údajom je absolútna výğka základného imania vkladaná do podnikov. Vzhădom na veŎ́é rozdiely medzi jednotlivými základnými imaniami boli tieto údaje analyzované v nadväznosti na Nalğ indikátor, podiel mesta na základnom imaní. Základné imanie vyğgie ako 1000000 EUR bolo dominantne pouǵité pri podnikoch s mestským podielom niǵğm ako 50\%. Následná implikácia teda je, ǵe vyğg̉e základné imanie bolo zväl ğa pouğité jednak pri akciových spolo! nostiach a jednak pri podnikoch s niğǵou úl as Šou samosprávy a pravdepodobne s vyğgou participáciou súkromného sektora. Pri hodnotení výǵky základného imania je potrebné braŠ oh@̆d aj na vzŞah medzi základným imaním a moǵným znehodnotením majetku samospráv vloǵeným do podniku v prípade konsolidácie záporného výsledku hospodárenia. Väl ğa pozornosŠ tomuto javu bude venovaná v odseku hodnotiacom výsledky hospodárenia.

Z hădiska podielu mesta na základnom imaní spolol nosti treba zdôrazniŠ, ǵe je väl g̉a tendencia zo strany miest byŠ $100 \%$ vlastníkom spolol ností s ruḷ eným obmedzením, ako akciových spolol ností. V prípade akciových spolol ností mestá vloǵili $100 \%$ základného imania iba v $21 \%$ prípadov, zatiaÖ o pri spol. s r.o. to bolo aǵ $73,8 \%$.

Na základe zistených faktov boli sformulované N̦alg̈e výskumné otázky týkajúce sa jednak vzŠahu medzi mierou majetkovej úl asti a zameraním podniku a jednak toho !̣i by mala byŠ preferovaná majetková úl as Š v podnikoch majoritná, teda s rozhodujúcim vplyvom, alebo menġinová (menej ako $50 \%)$.

Ústredný názor, ktorý sa medzi odpoveNami expertov vyskytol v prípade tejto otázky bol taký, ǵe pri zakladaní podnikov s majetkovou úlas ̌́ou miest by mestá mali braŠdo úvahy vğetky moǵné aspekty, prị om by sa mali snaǵs dosiahnuŠ ! o najväl ğu efektívnosડ̌ V prípade druhej ! asti otázky, medzi expertmi dominoval názor, ǵe obce by primárne mali byŠ $100 \%$ vlastníkmi podnikov s majetkovou úl asŠou miest. Meng̈e podiely experti pripustili len v prípade, ǵe ide o spoluprácu medzi viacerými obcami, pril om v spolo! nosti, kde je spoluvlastníkom subjekt súkromného sektora pripustili jedine vtedy, ak budú splnené viaceré podmienky (napr. právo veta) zo strany mestského zastupiteQ̆tva.

Dôleǵitým sledovaným javom v rámci analýzy je nepochybne podnikateQ̆ká úspeg̉nosŠ jednotlivých podnikov hodnotená na základe výsledkov hospodárenia, ktoré sa týmto podnikom podarilo dosiahnuŠ Z analyzovaných údajov vyplynulo, ǵe aǵ tretina podnikov kon! ila hospodárske roky 2009 
-2011 so stratou, pril om tieto straty dosahovali v priemere veăni vysoké hodnoty. Z tohto dôvodu treba uviesŠ ǵe podniky, ktoré dlhodobo dosahujú stratu musia stratu konsolidovaŠ odpisovaŠ zo základného imania. Vzhădom na to, ǵe ide o podniky, ktorých základné imanie bolo zloǵené mestom, podniky dosahujúce stratu, znehodnocujú mestský majetok. Efekty takéhoto nakladania s majetkom nie sú zväl ğ viditeăé z krátkodobého hădiska, avğk z dlhodobého hădiska môǵ spôsobovaŠ znal né problémy. Pri pohăde z druhej strany, teda zo strany podnikov, ktoré dosahovali zisk, je viac ako 55\% takých, ktoré sú stopercentnými dcérami mesta a len $20 \%$ týchto podnikov malo majetkovú úl asŠmesta niğğu ako 50\%. Z tohto dôvodu nie je opodstatnené konğatovanie, ǵe podniky, ktoré sú z majoritnej !̣asti vlastnené mestami sú menej konkurencieschopné, prípadne ekonomicky menej výkonné v porovnaní s podnikmi, kde majú mestá len minoritné podiely, a teda sú riadené prevaǵne manaǵérmi zo súkromného sektora.

Vzhădom na súvislosti medzi hospodárskym výsledkom a zameraním podniku moǵno kong̉atovaŠ ǵe z podnikov, ktoré $\mathrm{v}$ roku 2011 dosahovali zisk bolo $47 \%$ takých, ktoré za hlavný predmet podnikania uviedli !̣innosti, priamo súvisiace s výkonom samosprávnych kompetencií. Väl ġna podnikov, ktoré v roku 2011 dosiahli zisk, konkrétne 53\%, sa venujú iným, ako samosprávnym ! innostiam napr. v oblasti médií, lesného hospodárstva alebo sieŠových odvetví. Týmito faktami sa eǵe potvrdilo konġatovanie, ǵe mestá majú skôr tendenciu zakladania podnikov, ktoré sa nevenujú samosprávnym kompetenciám, prị om jednou z ich primárnych úloh sa zdá byŠ generovanie vlastných finan! ných prostriedkov pre samosprávy.

Tretia výskumná otázka kladená expertom vychádzala z tejto !̣asti analýzy a týkala sa postupu pri rozhodovaní o podnikoch s majetkovou úl asŠou miest, ktoré dlhodobo (dlhg̈e ako 3 roky) dosahujú stratu, majúc na pamäti znehodnocovanie majetku mesta konsolidáciou tejto straty na jednej strane, ale aj poskytovanie sluǵieb mestu na strane druhej. Odpovede na túto otázku primárne poukazovali na konfliktnosŠ súkromného a verejného aspektu v podnikoch s majetkovou úḷ aš̌ou miest, teda aspektu ziskovosti na jednej strane a poskytovania verejných sluğieb na strane druhej. V zásade sa vğk experti zhodli na výrazne negatívnych vplyvoch takéhoto hospodárenia na obec a na jej rozvoj a preto uviedli, ǵe pri stratovom podniku je potrebné pristúpiŠ k jeho likvidácii resp. transformácii. Objavil sa tieǵ motív vyvodenia osobnej zodpovednosti za takúto situáciu, ktorý momentálne v podmienkach Slovenska absentuje.

Z hădiska finan! nej previazanosti medzi podnikmi s majetkovou úlasŠou miest a rozpoḷtom samospráv je významný tieǵ údaj o výǵke príjmov do mestského rozpol tu plynúcich z podielu na zisku podniku. Na základe dotazníka bolo zistené, ǵe podniky, ktoré do mestských rozpoḷtov odvádzajú finan! né prostriedky, patria skôr k podnikom, v ktorých je podiel mesta na základnom imaní menğ ako 50\%, avğak tieto podniky sa primárne venujú ! innostiam, ktoré patria k samosprávnym kompetenciám.

V rámci charakteristiky podnikov, ktoré odvádzajú podiely na zisku do mestských rozpol tov, je dôleǵité uviesŠ ğe aǵ $82 \%$ z nich bolo zaloǵených pred rokom 2004. Naopak, z podnikov zaloǵených po tomto roku, len 3 odvádzajú podiely na zisku do mestského rozpol tu. Moǵno predpokladaŚ ǵe vzhădom na dlhğe pôsobenie na trhu, si starg̉e podniky vytvorili finan! ne stabilnejg̉u pozíciu, a teda existuje moǵnosŠ ǵe aj novg̉e podniky sa vlastným napredovaním a vývojom situácie na trhu po ! ase dostanú na ich úroveR

V takomto prípade vğk treba vziaŠ do úvahy aj druhú stranu a síce fakt, ǵe dlhodobým úspeg̉ným hospodárením podniku s majetkovou úl as Šou miest si tento podnik generuje vlastné prostriedky, ktoré síce pôvodom vychádzajú z verejných financií, avğgk po ich zhodnotení na trhu nemajú viac povahu verejných prostriedkov, ale súkromných. Preto pri podnikoch dlhodobo pôsobiacich na trhu je otázka odvádzania podielu na zisku diskutabilná.

Finan! ná napojenosŠ takýchto podnikov na mestské rozpol ty bola predmetom g̊vrtej výskumnej otázky kladenej expertom. Konkrétne sa týkala ich názoru na fakt ḷi by miera majetkovej úl asti mesta $\mathrm{v}$ podniku s majetkovou úl as ̌́ou miest mala súvisieŠs tým ḷ i sú takéto podniky orientované skôr na 
odvádzanie podielu na zisku mestám, alebo na opätovné investovanie do podniku a tieǵ !̣ i by poslanci mestského zastupiteQ̆tva mali maŠmoǵnosŠovplyvŔovaŠtoto rozhodnutie a akým spôsobom.

Experti sa zhodli na tom, ǵe neexistuje jeden vğeobecne vhodne aplikovateĞyý variant a vğdy by sa mal zváǵiš najvhodnejğ model, pril om najväl ğ dôraz by sa mal klásŠ na typ podniku a na zámer s akým bol podnik zakladaný. Obe stratégie môǵu prináğ́Š nesporné výhody, ktoré sa v konel nom dôsledku odzrkadQ̆ijú na celkovom ekonomickom rozvoji (napr. investície do podniku môǵu z dlhodobého hădiska viesŠ k tvorbe nových pracovných miest a odvádzanie podielu na zisku zas k zabezpel ovaniu kvalitnejğch sluğieb).

Vǵtci experti sa zhodli na tom, ǵe na tomto rozhodnutí by sa mali podieăš predstavitelia samosprávy, avğak bol spomenutý názor, ǵe by malo ísŠ len o poslancov, ktorí sú ḷ lenovia dozornej rady podniku, aby sa eliminoval politický aspekt a zachoval aspekt odbornosti. Takéto rozhodnutie poslancov by malo byŠzakomponované do Zásad hospodárenia s majetkom mesta.

Posledným indikátorom finan! nej povahy, ktorý bol v rámci dotazníkového prieskumu sledovaný bola výğka finan! ných prostriedkov, vakej podnik vyfakturoval mestu realizované sluğby poḷ as rokov 2009 aǵ 2011. Z podnikov, ktoré na dotazník reagovalo, 64\% je na rozpol ty miest napojených dodávateQ̆ko - odberateQ̆kými vzŠahmi.

Je teda moǵné konğatovaŠ ğe jedným z dôvodov, pre ktoré si mestá zakladajú podniky s majetkovou úl asŠou miest je práve poskytovanie sluğieb mestám. Otázne vğak je !̣ i tieto sluğby priamo súvisia s výkonom samosprávnych kompetencií, a teda !̣i ide o poskytovanie verejných sluǵieb obyvateØ̆m. OdpoveN̦ nie je jednoznal ná, keṆǵe len pribliǵne polovica podnikov, ktoré sluğby vyfakturovali, uviedla ako svoj hlavný predmet také ! innosti, ktoré sa priamo dotýkajú niektorých zo samosprávnych kompetencií. Druhá polovica podnikov, ktoré mestám fakturujú svoje sluǵby sú napr. televízie, prevádzky spadajúce do oblasti cestovného ruchu, teplárenské spoloḷ nosti atṆ.

V rámci problematiky poskytovania sluğieb mestu zo strany podnikov s majetkovou úl asŠou miest sa otvára tieǵ otázka stanovenia ceny za takéto sluǵby. Na základe rozhovoru s predstaviteŏm samosprávy bolo zistené, ǵe mestá majú spravidla so svojimi podnikmi uzatvorené zmluvy dlhodobejğeho charakteru (pribliǵne 5 rokov) pril om vývoj cien je v rámci takejto zmluvy og̉etrený jedine z hQ̆diska medzirol nej inflácie. Ceny sluǵieb, ktoré si podniky s majetkovou úl asŠou miest fakturujú zväl ğa nie sú testované trhom v prirodzenom konkuren!̣ nom prostredí. Z tohto dôvodu môǵ nastaŠnapríklad tieto prípady:

- ceny sú nastavené prílig̉ nízko, v prospech samosprávy a tým pádom je eliminovaná schopnosŠ firiem reprodukovaŠmajetok firmy,

- ceny sú nastavené vysoko, ale vzhădom na zmluvy uzatvorené na dlhé obdobie nemôǵu mestá flexibilne reagovaŠna zmeny situácie na trhu.

Mechanizmus stanovenia ceny za sluǵby v prípade, ǵe ide o dodávateQ̆ko - odberateQ̆ký vzŠah medzi mestom a podnikom s majetkovou úl asŠou mesta predstavoval podstatu poslednej piatej výskumnej otázky.

Odpovede naznal ujú, ǵe ceny sluğieb poskytovaných podnikmi s majetkovou úl asŠou miest by mali byŞodvodené od reálnych nákladov, ktoré sú porovnané s cenami na voĞom trhu a sú postavené na objektívnej ekonomickej analýze. Táto analýza vg̉k musí braŠ do úvahy cieŎ pre ktorý podnik vznikol. Vǵeobecne tieǵ platí, ğ́ ceny sluğieb poskytovaných priamo mestu by mali byŠ výhodné pre obe strany.

\section{Závery}

Podniky s majetkovou úl asŠou miest sú v súḷasnosti rozğreným javom nielen v podmienkach Slovenska, ale aj v zahraniḷ̂́. Napriek tomuto faktu existuje mnoǵstvo aspektov spojených $\mathrm{s}$ fenoménom podnikania miest, ktoré nie sú podloǵené aktuálnou legislatívou, prípadne zauğ́vanými ġandardami a postupmi v rámci tzv. dobrej praxe. Vykonaná analýza determinantov (identifikal ných, 
vlastníckych, ekonomických a obchodných) vzŠahujúcich sa na podnikanie s majetkovou úḷ asŠou miest viedla $\mathrm{k}$ formulácii viacerých problémov ich fungovania.

V rámci identifikal ných determinantov bola nastolená otázka zamerania podnikov s majetkovou úl asŠou miest, ktorá viedla $\mathrm{k}$ formulácii názoru, ǵe takéto podniky by mali byŠ vo svojej podstate orientované na výkon samosprávnych kompetencií. So zameraním podnikov priamo súvisela aj problematika závislosti medzi mierou majetkovej úl asti a zameraním podniku, pri ktorej neexistuje jednoznal ná odpoveN, pril om dôraz by za kaǵdých okolností mal byŠ kladený na dosiahnutie maximálnej moǵnej efektívnosti. Vǵeobecná prax by vğkk mala byŠ taká, ǵe okrem výnimol ných prípadov, by mali byŠ mestá $100 \%$-nými vlastníkmi podnikov, v ktorých majú majetkovú úl as Š $\mathrm{Z}$ analýzy ekonomických determinantov vyplynul názor, ǵe podniky, ktoré viac ako tri roky dosahujú ako výsledok hospodárenia stratu, by mali podstúpiŠ likvidáciu resp. transformáciu a to aj napriek tomu, ǵe pre mesto poskytujú verejné sluğby.

V rámci obchodných determinantov, experti identifikovali vzŠah medzi mierou majetkovej zainteresovanosti podnikov a faktu !̣ i tieto podniky odvádzajú podiely na zisku zakladateQ̆kým mestá, alebo tieto prostriedky vyuğivajú ako investície pre N̦alg̈u svoju !̣ innosŠ a rozvoj. V prípade tejto otázky je kđ̛̣|lovým úl el, na aký boli podniky zakladané, prị om toto rozhodnutie by malo byŠ v kompetencii tých poslancov mestského zastupiteQ̆tva, ktorí sú !̣lenmi dozornej rady podniku. Rozhodnutie poslancov by malo byŠ zakotvené v Zásadách hospodárenia s majetkom mesta. V rámci príspevku bola pozornosŠ venovaná aj otázke stanovovania ceny za sluğby poskytované mestu podnikom s majetkovou úlasŠou tohto mesta. Ceny sluǵieb by mali byŠ odvodené od reálnych nákladov, postavené na objektívnej ekonomickej analýze, pril om by malo ísŠo ceny výhodné pre obe strany.

Zadefinované gaandardy fungovania podnikov, napriek tomu, ǵe nemajú oporu v platnej legislatíve, by pri ich implementácii mali slúǵŠ k zefektívneniu fungovania podnikov s majetkovou úl asŠou miest. Stabilnejg̈e postavenie týchto podnikov by viedlo k efektívnejg̈emu hospodáreniu s majetkom miest, ! o by sa v konel nom dôsledku odrazilo v zlepǵení finan! nej situácie slovenských samospráv.

\section{Literatúra}

[1] ALEKSEEV I. A., (2013). Comparative ï Legal Analysis of the Legal Responsibility of the Bodies and Official Functionaries of Local Self-Government in Foreign Countries. Middle-East Journal of Scientific Research, vol. 17, iss. 11, pp. 1525-1531. ISSN 1990- 9233. DOI 10.5829/idosi.mejsr.2013.17.11.12326.

[2] BUMBALOVÁ, M., (2013). Efekty determinantov zhodnocovania majetku obcí v miestnom ekonomickom rozvoji: dizerta! ná práca, Nitra: SPU.

[3] HAMALOVÁ, M., BELAJOVÁ, A., (2011). Komunálna ekonomika a politika, Bratislava: VĠMVS. ISBN 978-80-89393-38-1.

[4] KLIMOVSKÝ, D., (2008). Základy verejnej správy, Kog̉ce: UPJĠ ISBN 978-80-7097-713-2.

[5] OPLOTNIK, Z.J., BREZOVNIK, B., VOJINOVIC, B., (2012). Local Self-government Financing and Costs of Municipality in Slovenia. Transylvanian Review of Administrative Science. 37E, pp. 128- 142. ISSN $1842-2845$.

[6] PAULIL KOVÁ, A., (2010). Economic Crisis and Enhanced Competitiveness of Municipalities. Danube. 2, vol. 2010, iss. 4, pp. 31-39. ISSN 18046746a.

[7] Transparency International., (2007). Nakladanie s majetkom v krajských mestách SR. Hodnotiaca správa. [online]. [cit. 2012-3-28] Dostupné z <http://backup.transparency.sk/aktuality/finalnakladaniesprava1.pdf.>.

[8] G̦ÁRSKA, E. et al., (2007). Komunálna ekonomika a politika, Bratislava: Ekonóm. ISBN 978-80-2252293-9.

[9] Zákon ! . 369/ 1990 Zb. o obecnom zriadení v znení neskorğch predpisov.

Príspevok bol spracovaný v rámci grantu podporeného Kultúrnou a eduka!̣ou grantovou agentúrou Ministerstva ǵkolstva, vedy, výskumu a g்ortu Slovenskej republiky na základe projektu s názvom Ekonomika a manaǵnent verejných sluǵeb pod@̆ zmluvy !. O31SPU-4/20. 